\title{
What do new intimidation laws mean for health workers and patients?
}

\author{
Cite as: CMAJ 2022 March 7;194:E345-6. doi: 10.1503/cmaj.1095988
}

Posted on cmajnews.com on February 17, 2022

$\mathbf{N}$ ew criminal sanctions against intimidating health workers may provide additional legal protections for those facing increasing abuse on the job, including during protests against pandemic mandates. But so far police do not appear to be enforcing the new rules any more than previous laws on harassment.

As of January 16 , it is illegal to intimidate people to impede them from providing, assisting or accessing health care services in Canada. Introduced by the Liberal government as part of Bill-C3, the new Criminal Code amendments also make it illegal to obstruct or interfere with another person's access to health care facilities. People convicted of either offence face a maximum sentence of up to 10 years in prison.

According to Ian McLeod of Canada's Department of Justice, the amendments "express Parliament's grave concerns about various kinds of aggressive and violent behaviour targeting health care workers and seekers."

Health workers have a fourfold higher rate of workplace violence than any other profession. Fewer than half of these incidents are reported. Fewer still are ever reported to the police.

McLeod said the new amendments provide "additional tools" for prosecutors and law enforcement to lay charges in such cases.

Criminal harassment, uttering threats, and obstructing hospital access were already criminal offences prior to the new amendments coming into force. But according to Justice Minister David Lametti, police rarely applied those charges in cases involving the harassment of health workers.
At least two people have been arrested and charged under the new sanctions in connection with a protest at the home of Peterborough's medical officer of health.

Yet, some health workers are questioning why police do not appear to be laying similar charges when it comes to the trucker convoy protests that gridlocked cities across Canada.

In Ottawa, anti-government protesters threw rocks at paramedics, assaulted people wearing masks, and blocked access to health facilities. In Calgary, demonstrators bullied staff entering and exiting an urgent care centre, delayed ambulances, and banged on clinic windows. And in Toronto, student volunteers rallied to escort health workers and patients through groups of aggressive picketers.

Police and health facilities have warned workers to take precautions including staying indoors and avoiding wearing masks or clothes that might identify them - a response that some have likened to telling women to dress modestly to avoid street harassment.

In an open letter cosigned by the heads of the Canadian Medical Association and the Registered Nurses Association of Ontario, more than 1600 health workers called on the police to enforce Bill C-3. "We will not cower. We will not hide," the letter states.

According to Caryma Sa'd, a Torontobased lawyer, the new amendments theoretically provide a "clearer avenue" for police to arrest aggressive picketers. However, "we're throwing in additional ammunition to police who have already proven themselves, for whatever reason, reluctant to lay charges using other provisions."
Police services contacted by CMAJ did not answer directly as to why preexisting sanctions were underutilized.

Toronto Police Services said it follows guidance from the Canadian Association of Chiefs of Police, or CACP.

A CACP spokesperson said the police community welcomes the new legislation and will recommend charges "when the situation and evidence support it." The spokesperson also noted that the new legislation will "help bolster our ability to pursue crimes in the cyber world."

Meanwhile, Calgary Police Services said it will "continue to look into these new provisions to educate and train its members accordingly." Notably, "the right to peacefully protest does not extend to allowing acts of criminal intimidation or harassment under the Criminal Code."

\section{What to do when facing intimidation}

Typically, when it comes to criminal offences, the police must recommend charges and a prosecutor must approve them. However, if the police or Crown decide not to proceed with charges, anyone who has reasonable grounds to believe that another person has committed a crime may provide that information to a justice of the peace in order to have the issue brought to court.

Sa'd recommends that people experiencing intimidation document as much as possible, as soon as possible. "Take screenshots, recordings, or photographs if you feel safe doing so. That's the best thing you can do at the outset to protect yourself because that's going to create an evidentiary record." 
She adds that documenting such encounters can be "retraumatizing," so it can be helpful to ask friends and trusted colleagues to assist you in gathering information.

The sanctions on intimidation broadly cover "any conduct with the intent to provoke a state of fear" in order to impede health care access or delivery. A person will not be held guilty of obstructing or interfering with access to care if they only approach a health facility "for the purpose of obtaining or communicating information."

According to Dr. Steven Bellemare of the Canadian Medical Protective Association (CMPA), "it's very hard to predict what will constitute the intent to provoke fear" because the law is so new.

However, he said the amendments open the door for health workers and patients to report situations where they were "made to feel fearful," even if there is no imminent threat of violence. Physicians experiencing harassment can also contact the CMPA to help determine next steps.

"When people are gathered in front of your workplace or maybe even in front of your home, brandishing signs and yelling at you - that was not a crime before and now it is. That's the expanded breadth," Bellemare told CMAJ.

Until there's a track record of successful prosecutions under the new amendments, police may bundle intimidation and criminal harassment charges. "It's harder to weasel out of criminal harassment because that has much more established definitions and established cases," said Tonya Kent, a Torontobased criminal defence lawyer.
Criminal harassment can include repeated phone calls, emails and social media messages, as well as showing up uninvited at a person's home or work.

Kent said it can be helpful in such cases to clearly tell the person in writing to stop the behaviour. "If they continue to do it, you can bring that written proof."

\section{Diana Duong, with files from Lauren Vogel, CMAJ}

Content licence: This is an Open Access article distributed in accordance with the terms of the Creative Commons Attribution (CC BY-NC-ND 4.0) licence, which permits use, distribution and reproduction in any medium, provided that the original publication is properly cited, the use is noncommercial (i.e., research or educational use), and no modifications or adaptations are made. See: https://creativecommons. org/licenses/by-nc-nd/4.0/ 